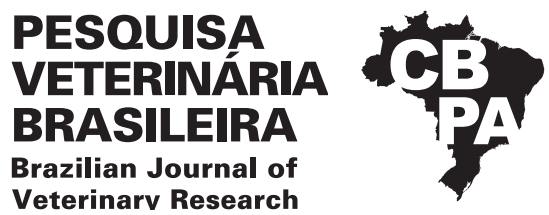

Pesq. Vet. Bras. 40(6):409-416, June 2020 DOI: 10.1590/1678-5150-PVB- 6629

Veterinarv Research

ISSN 0100-736X (Print)

ISSN 1678-5150 (Online)

\title{
Primary hepatic neoplasms in cattle ${ }^{1}$
}

\author{
Andréia Vielmo $^{2 *}$ (D), Welden Panziera ${ }^{2}$ (D), Matheus V. Bianchi ${ }^{2}$ (D), \\ Fernando F. Argenta ${ }^{2}$ (D), Cíntia De Lorenzo² (D), Luís A. Vielmo ${ }^{3}$, \\ Saulo P. Pavarini ${ }^{2}$ (D) and David Driemeier ${ }^{2}$ (D)
}

\begin{abstract}
Vielmo A., Panziera W., Bianchi M.V., Argenta F.F., Lorenzo C., Vielmo L.A., Pavarini S.P. \& Driemeier D. 2020. Primary hepatic neoplasms in cattle. Pesquisa Veterinária Brasileira 40(6)409-416. Setor de Patologia Veterinária, Departamento de Patologia Clínica Veterinária, Faculdade de Veterinária, Universidade Federal do Rio Grande do Sul, Av. Bento Gonçalves 9090, Prédio 42505, Porto Alegre, RS 91540-000, Brazil. E-mail: andreiavielmo@yahoo.com.br

Primary hepatic neoplasms are mostly detected in cattle as incidental findings in slaughterhouses or diagnosed at the necropsy, wherein it may be related to the cause of death. A proper characterization of primary hepatic neoplasms is essential to provide an accurate diagnosis, especially at the slaughter lines, in order to reduce erroneous condemnations. This work aimed to characterize the gross, histological, and immunohistochemical features of primary liver neoplasms detected in slaughtered cattle in Southern Brazil. Nineteen primary hepatic neoplasms were identified. Grossly, these lesions were classified according to their distribution, as focal, multifocal, or diffuse. Histologically, the shape and arrangement of the cells, as well as possible malignant features were evaluated. Immunohistochemistry (IHC) was also performed for biliary epithelium (anti-CK7) and hepatocytes (anti-Hep Par1) markers. Hepatocellular carcinoma $(84.2 \%)$ was the most frequently detected hepatic neoplasm, followed by cholangiocarcinoma (15.8\%), and these were only identified in adult cows. Hepatocellular carcinomas occurred as solitary masses or multifocal nodules, which on the cut surface were often green. Cholangiocarcinomas occurred as multifocal nodules, occasionally showing an umbilicated appearance. Histologically, hepatocellular carcinomas had mostly trabecular and solid patterns, while cholangiocarcinomas presented mostly a solid arrangement. Upon IHC, all hepatocellular carcinomas were immunolabeled for anti-Hep Par1 , ranging from mild (25\%), moderate $(31.2 \%)$ to marked (43.7\%), while immunolabeling for anti-CK7 was detected only in one case of cholangiocarcinoma.
\end{abstract}

INDEX TERMS: Neoplasms, cattle diseases, abattoir study, hepatic tumors, hepatocellular carcinoma, cholangiocarcinoma, hepatic markers.

\begin{abstract}
RESUMO.- [Neoplasmas hepáticos primários de bovinos.] Os neoplasmas hepáticos primários são detectados em bovinos principalmente como achados incidentais em matadouros ou diagnosticados na necropsia, quando podem estar relacionados à causa da morte. A caracterização adequada dos tumores hepáticos primários é essencial para obter diagnósticos precisos, especialmente nas linhas de abate, com o propósito de reduzir condenações errôneas. Este trabalho teve o objetivo
\end{abstract}

\footnotetext{
${ }^{1}$ Received on March 10, 2020.

Accepted for publication on March 24, 2020.

${ }^{2}$ Setor de Patologia Veterinária, Departamento de Patologia Clínica Veterinária, Faculdade de Veterinária, Universidade Federal do Rio Grande do Sul (UFRGS), Av. Bento Gonçalves 9090, prédio 42505, Porto Alegre, RS 91540-000, Brazil. *Corresponding author: andreiavielmo@yahoo.com.br

${ }^{3}$ Ministério da Agricultura e Abastecimento (MAPA), SIF 1733, BR-392, Passo das Tropas, Santa Maria, RS 97070-160, Brazil.
}

de determinar as características macroscópicas, histológicas e imuno-histoquímicas dos neoplasmas primários do fígado de bovinos abatidos em um matadouro-frigorífico no Sul do Brasil. Dezenove neoplasias hepáticas primárias foram identificadas. Macroscopicamente, os tumores hepáticos foram classificados de acordo com sua distribuição, como focais, multifocais ou difusos. Histologicamente, a forma e o arranjo das células e possíveis características malignas foram avaliados. Também foi realizada imuno-histoquímica (IHQ) para marcadores de epitélio biliar (anti-CK7) e hepatócitos (anti-Hep Par-1). O carcinoma hepatocelular (84,2\%) foi o neoplasma hepático mais frequentemente detectado, seguido pelo colangiocarcinoma (15,8\%). Esses tumores foram identificados apenas em vacas adultas. Os carcinomas hepatocelulares eram vistos como massas solitárias ou nódulos multifocais que na superfície de corte geralmente 
eram esverdeados. Os colangiocarcinomas foram observados como nódulos multifocais, ocasionalmente com aspecto umbilicado. Histologicamente, os padrões mais observados nos carcinomas hepatocelulares foram trabeculares e sólidos, enquanto nos colangiocarcinomas o arranjo sólido foi o mais frequente. $\mathrm{Na} I \mathrm{HQ}$, todos os carcinomas hepatocelulares foram marcados por anti-Hep Par-1, com marcação que variou de leve $(25 \%)$, moderada $(31,2 \%)$ a acentuada $(43,7 \%)$; imunomarcação para anti-CK7 foi detectada em apenas um caso de colangiocarcinoma.

TERMOS DE INDEXAÇÃO: Neoplasmas, bovinos, doenças de bovinos, estudo em abatedouro, tumores de fígado, carcinoma hepatocelular, colangiocarcinoma, marcadores hepáticos.

\section{INTRODUCTION}

Primary hepatic neoplasms (PHN) are uncommon in domestic animals, except in dogs, and are generally hepatocellular or cholangiocellular in origin (Cullen \& Stalker 2016). In cattle, PHN frequency varies geographically, with incidences ranging from 3.1 to $10 \%$ in South Africa and in the United Kingdom (UK), respectively (Anderson \& Sandinson 1968, Bastianello 1982). Recent data from Brazilian studies (Lucena et al. 2011, Tessele \& Barros 2016, Reis et al. 2017) indicated lower frequencies of 1.88-4.6\% of liver tumors when compared to other studies (Anderson \& Sandinson 1968). Overall, lymphoma (enzootic bovine leucosis) and squamous cell carcinoma are the most common detected bovine neoplasms. The latter may occur in the upper alimentary tract, the eyes and adnexa, and in the vulva (Lucena et al. 2011, Rosa et al. 2012, Carvalho et al. 2014, Mello et al. 2017, Reis et al. 2017).

Primary tumors that originate from hepatocytes may include adenomas, hepatocellular carcinomas, and hepatoblastomas, while those originated from the biliary epithelium are classified as adenomas, biliary cystadenomas, cholangiocarcinomas, or biliary cystadenocarcinomas (Head et al. 2003, Cullen 2017). Mixed hepatocellular and cholangiocellular carcinomas are rarely observed and have histological characteristics of both cell origins: hepatocytes and biliary epithelium (Cullen 2017).

The diagnosis of PHN is not always obtained based solely on histological characteristics; on these instances, immunohistochemical exams are essential to establish a conclusive diagnosis. Several immunohistochemical markers may assist in the differential diagnosis of liver tumors (Chan \& Yeh 2010), such as hepatocyte paraffin 1 (Hep Par-1), which is used to label neoplastic hepatocytes and, thus, identify hepatocellular carcinomas (Chu et al. 2002), and cytokeratin 7 (CK7), which labels bile duct epithelial cells (Yabushita et al. 2001), allowing a proper recognition of cholangiocarcinomas.

The characterization of PHN is important to improve the accuracy of identification in meat inspection lines. According to the Industrial Regulation of Animal Producer Inspection (Ministério da Agricultura 2017), carcasses, part of them, or organs affected by malignant tumors must be condemned, regardless of the occurrence of metastases. Thus, the difficulty in the diagnosis may lead to an incorrect destination of the carcass (Freitas 1999). In order to assist veterinary pathologists and meat inspectors, as well to improve diagnostic accuracy, this study aimed to characterize the gross, microscopic, and immunohistochemical aspects of PHN detected in slaughtered cattle in Southern Brazil.

\section{MATERIALS AND METHODS}

From 2015 to 2016, liver samples of cattle slaughtered in an abattoir of the municipality of Santa Maria, Rio Grande do Sul state ( $29^{\circ} 46^{\prime} 54.2^{\prime \prime} \mathrm{S}$; $53^{\circ} 46^{\prime} 38.8^{\prime \prime} \mathrm{W}$ ) were collected. These samples, previously fixed in $10 \%$ formalin, were sent for gross and histological evaluation after condemnation at the meat inspection line. Metastases were also sent for analysis.

The slaughtered cattle were from different regions of the state. For this study, only those livers with PHN were selected. The samples were photographed, trimmed, routinely processed for histology, and stained by hematoxylin and eosin (HE). Data regarding sex and age (estimated by dentition) (Food Safety Inspection Service 2013) of the cattle involved were obtained from the slaughterhouse files.

Grossly, PHN were classified according to their distribution into focal, multifocal, or diffuse. Focal tumors appeared as a single nodule or mass in the liver. Tumors distributed as multiple nodules or masses with a random distribution in the liver parenchyma were included in the multifocal category. Diffuse neoplasms affected all or most parts of the liver. In this latter pattern, there was an increase in the whole volume of the organ, accompanied by changes in color and consistency of the affected part.

Histological evaluation was performed according to previously established criteria (Cullen 2017). The following features were considered: (1) cellular arrangement; (2) stromal pattern; (3) cell pleomorphism; (4) vascular or lymphatic invasion; (5) necrosis, hemorrhage, and intratumoral inflammatory infiltrate; (6) intratumoral vascular spaces; and (7) mitotic index. The degree of mitoses was evaluated by three independent veterinary pathologists and considered as mild (less than or equal to one mitosis per high power field - 400x), moderate (2-4 mitosis per high power field), and marked (greater than five mitoses per high power field).

In order to assess desmoplasia levels and mucin content, histological sections of the neoplasms were stained by Masson's trichrome (MT) and Periodic Acid Schiff (PAS), respectively. Selected sections of the neoplasms were submitted to immunohistochemistry (IHC) using the universal polymer method marked with peroxidase (MACH 4 Universal HRPPolymer - Biocare Medical) for the biliary epithelium [monoclonal antibody anti-cytokeratin-7 (anti-CK7); clone/brand: M7018/ Dako; dilution 1:40; antigenic retrieval proteinase $\mathrm{K}]$ and hepatocytes [monoclonal antibody anti-hepatocyte paraffin 1 (anti-Hep Par-1); clone/brand: M7018/Dako; dilution 1:40; antigenic retrieval citrate buffer $\mathrm{pH} 6.0$ for $40 \mathrm{~min}$ at $\left.96^{\circ} \mathrm{C}\right]$. For both protocols, revelation was obtained by using the chromogen 3-amino-9-ethylcarbazole (AEC) and counterstain with Mayer's hematoxylin. As a positive control, a section of the liver previously tested was used, and the same material was used as a negative control, by replacing the primary antibody with phosphate-buffered saline. The immunolabeling intensity was classified as absent, mild, moderate, or marked.

\section{RESULTS}

Nineteen primary hepatic neoplasms were identified during the period studied, of which 16 (84.2\%) were hepatocellular carcinomas and three (15.8\%) cholangiocarcinomas. All affected cattle were adults above 3-year-old. Female cattle were mostly affected, both in cases of hepatocellular carcinomas 
$(93.75 \%, 15 / 16)$, and in cases of cholangiocarcinoma $(66.7 \%$, $2 / 3)$. Grossly, hepatocellular carcinomas were focal in $43.7 \%$ (Fig.1A) of the cases, multifocal in $43.7 \%$ (Fig.1B), and diffuse in $12.5 \%$ (Fig.1C). The focal pattern occurred as nodules measuring $4-17 \mathrm{~cm}$ in diameter, which occupied and partially effaced the affected hepatic lobe. The multifocal pattern occurred as random nodular areas, ranging from 1-20 cm in diameter. In the diffuse pattern, the entire organ was affected. The neoplastic masses were white, yellow or red, and soft or firm. The cut surface showed white, yellow, dark green (Fig.1D) and red areas. Occasionally there were extensive friable areas (necrosis) intermixed with the tumor mass.

Histologically, hepatocellular carcinomas had a solid pattern in half of the cases (Fig.2A) and trabecular pattern in the other half (Fig.2B). In the solid pattern, the hepatic architecture was disorganized by the proliferation of dense mantles of neoplastic hepatocytes. Trabeculae of varying thickness formed by neoplastic cells characterized the trabecular pattern. Neoplastic cells were polygonal, with distinct cytoplasmic boundaries, abundant and faint eosinophilic, sometimes vacuolated, cytoplasm. Nuclei were rounded, with finely stippled chromatin, containing one to five evident nucleoli. Binucleated or multinucleated neoplastic hepatocytes were observed in $56.2 \%$ of the tumors (Fig.2C). Inflammatory infiltrate of lymphocytes, plasma cells, neutrophils, and macrophages occurred in $87.5 \%$ of hepatocellular carcinomas; while in 25\% of the cases, there were intratumoral vascular spaces, and in $6.25 \%$ there was discrete multifocal mineralization. Vascular invasion (blood or lymphatic) occurred in $37.5 \%$ of the cases (Fig. 2D). Among the tumors with vascular dissemination, $25 \%$ had a solid pattern and $12.5 \%$ a trabecular pattern. Extrahepatic metastasis (to mediastinal lymph node) of a solid pattern hepatocellular carcinoma occurred in one case (Fig.2E). Additional histological characteristics of hepatocellular carcinomas are summarized in Table 1.

IHC for anti-Hep Par-1 revealed an intracytoplasmic granular immunolabeling ranging from mild (25\% of cases), moderate (31.2\% of cases) to marked (43.7\%) (Fig.2F). IHC anti-CK7 did not reveal any labeling for hepatocellular carcinomas.
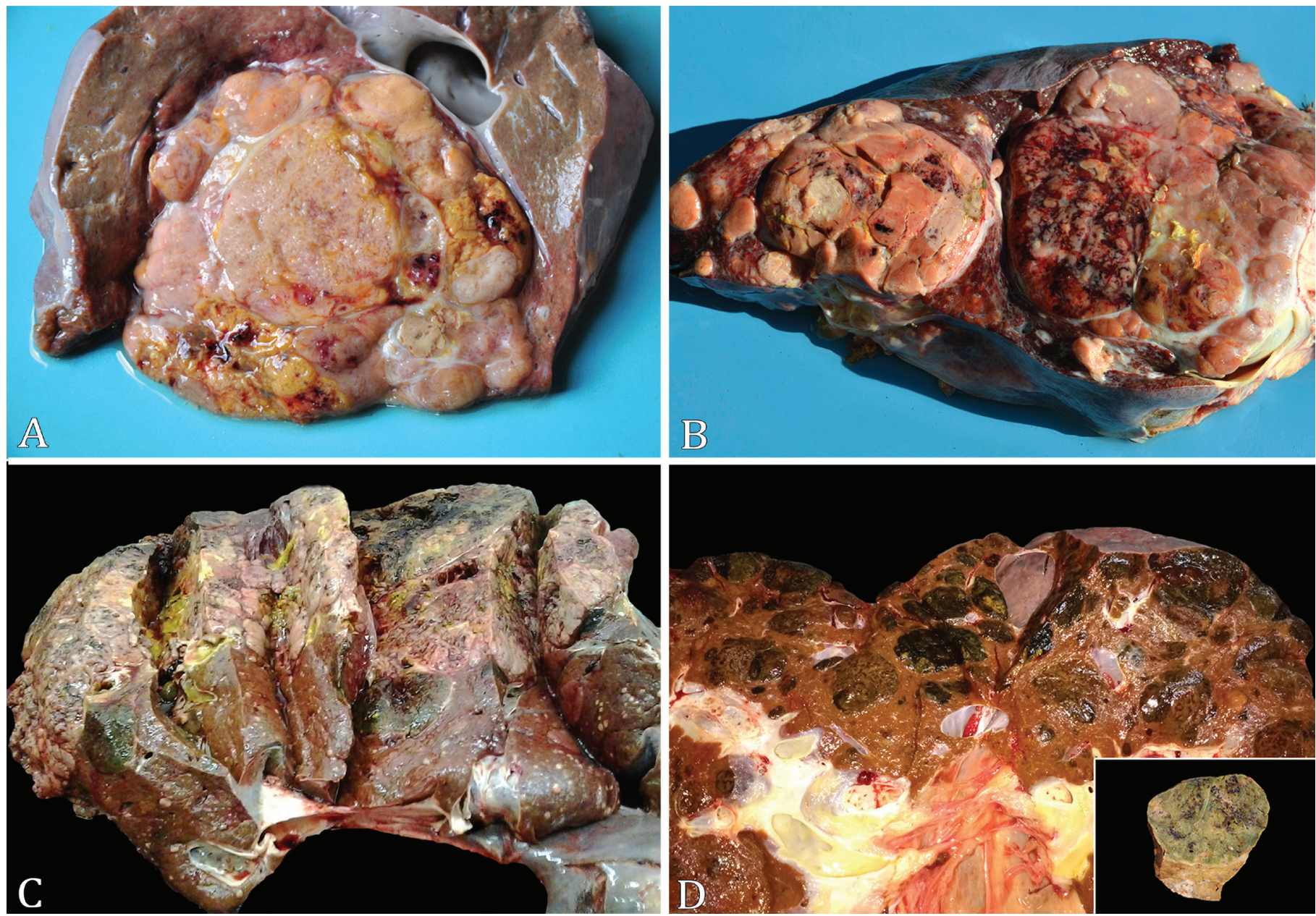

Fig.1. Gross aspects of hepatocellular carcinomas in cattle. (A) Focal pattern. A nodular area partially effaces the liver parenchyma. The cut surface has a predominance of white areas interspersed with yellow to red foci. (B) Multifocal pattern. Multiple nodular structures of different sizes are observed. The cut surface is similar to that of Figure 1A, with extensive red areas. (C) Diffuse pattern. The neoplasm almost completely replaces the liver parenchyma. Within the tumor parenchyma, there are friable green areas. (D) Cut surface. Darkgreen nodular multifocal areas are distributed randomly across the parenchyma. Inset: a formalin-fixed liver fragment with a green nodular area. 
Grossly, all three cholangiocarcinomas had a multifocal pattern of liver involvement, which was characterized by slightly irregular, occasionally umbilicated, and firm nodules of $1-6 \mathrm{~cm}$ in diameter, randomly distributed within the liver parenchyma. On the cut surface, these nodules were white to yellow.
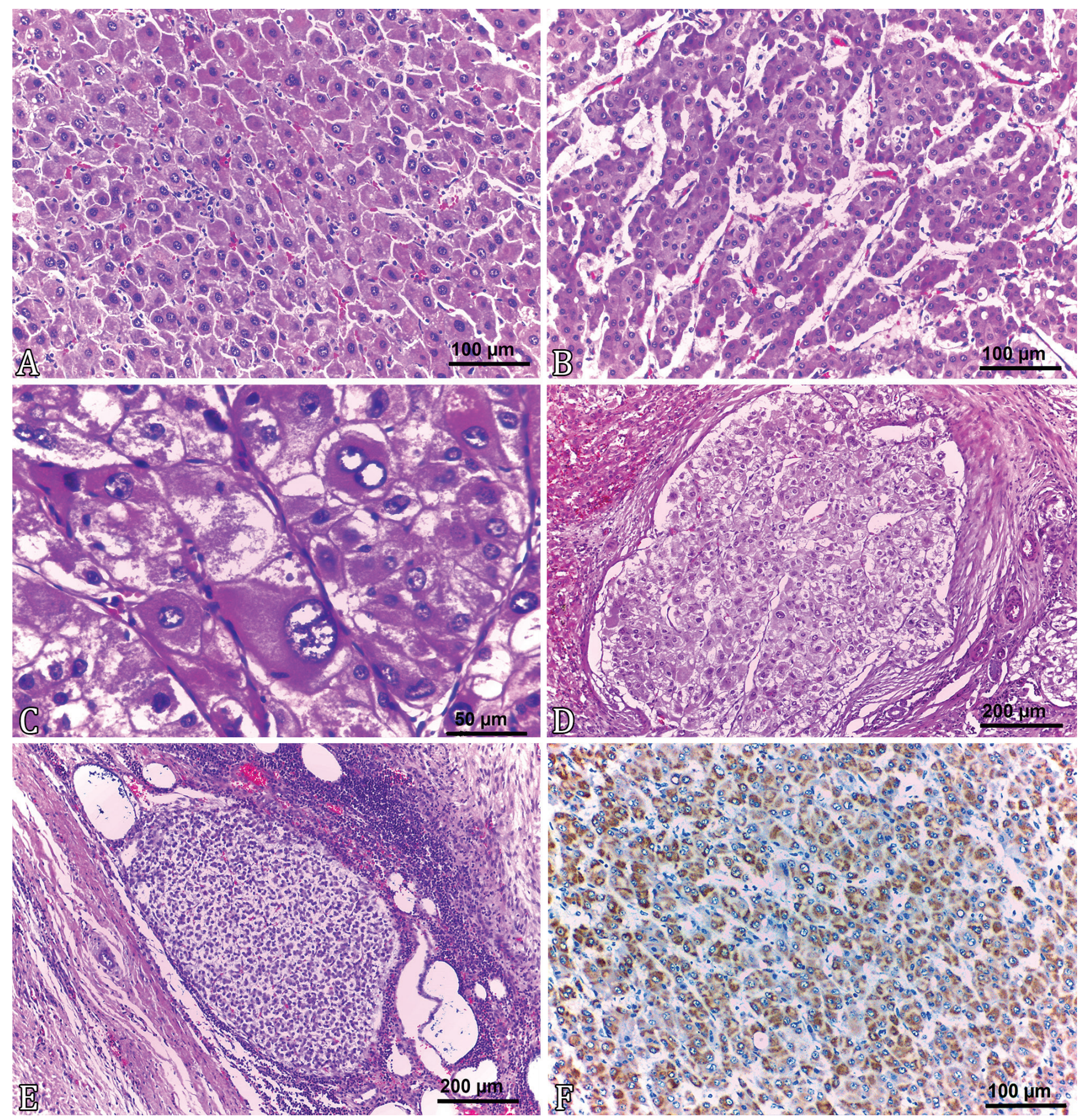

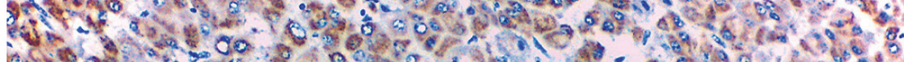

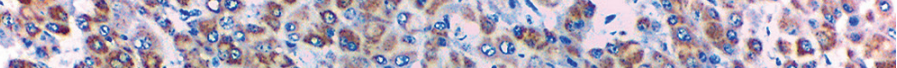

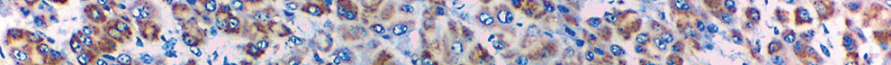

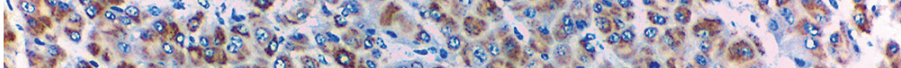

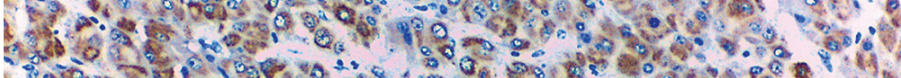

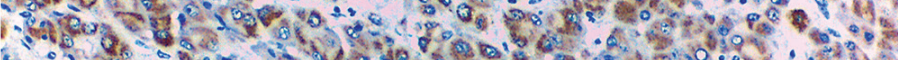

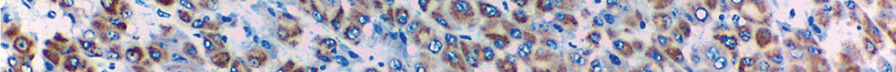

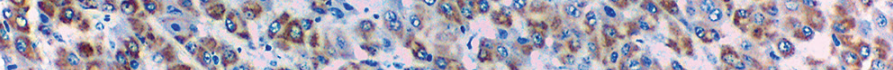

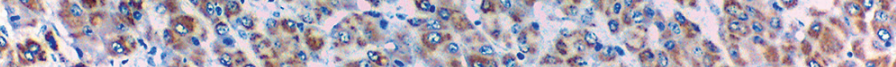

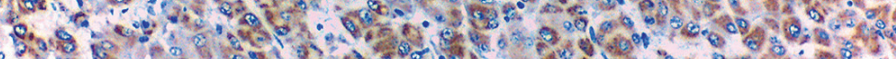

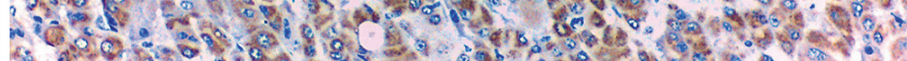
of 0 .

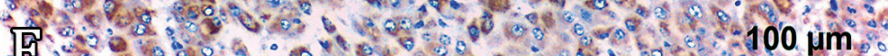

Fig.2. Histological and immunohistochemical aspects of hepatocellular carcinomas in cattle. (A) Solid pattern. The parenchyma is replaced by a mantle of neoplastic hepatocytes displaying marked nuclear pleomorphism. HE, bar $=100 \mu \mathrm{m}$. (B) Trabecular pattern. The neoplastic hepatocytes are arranged in trabeculae of varying thickness. Unlike Figure 2A, the tumor cells are well differentiated. HE, bar $=100 \mu \mathrm{m}$. (C) Cellular pleomorphism characterized by marked anisocytosis and binucleated and vacuolated neoplastic hepatocytes $\mathrm{HE}$, bar $=50 \mu \mathrm{m}$. (D) Embolus of neoplastic cells occluding the lumen of a blood vessel within the liver parenchyma. $\mathrm{HE}$, bar $=200 \mu \mathrm{m}$. (E) Metastasis of hepatocellular carcinoma in a lymph node. In the medullary sinuses, a blood vessel is obliterated by tumor cells. HE, bar $=200 \mu \mathrm{m}$. (F) There is a marked diffuse granular immunolabeling in the cytoplasm of neoplastic cells. Anti-Hep Par-1 IHC, AEC chromogen, bar $=100 \mu \mathrm{m}$. 
Histologically, the solid pattern occurred in two out of three cases (Fig.3A); in the remaining case, the neoplasm was arranged in acini or irregular ducts (Fig.3B). In both histological patterns, neoplastic cells partially effaced the liver parenchyma. The cells varied from cuboidal to rounded, with indistinct cytoplasmic borders, moderate and faint eosinophilic cytoplasm. Nuclei were predominantly oval, with finely stippled chromatin and one to three evident nucleoli. Cellular pleomorphism was moderate in two cases and marked in the other, in which there was marked anisocytosis and anisokaryosis (Fig.3C). The mitotic index was mild (1/3), moderate (1/3), or marked (1/3). Fibrous connective tissue proliferation was observed in HE stained sections (Fig.3D) and evidenced by the MT technique (Fig.3E), in which it was mild in one of the tumors and marked in the other two (scirrhous cholangiocarcinomas). Mild (two cases) and moderate (one case) areas of necrosis and hemorrhage were also observed within the neoplasm parenchyma. Vascular invasion was found in two cases, and in one of the tumors, there was pulmonary metastasis. In all three cases, there was mild intratumoral inflammatory infiltrate of lymphocytes, plasma cells, neutrophils, and macrophages. A mild amount of mucin was evidenced within the neoplastic ducts in two cases by the PAS technique. Upon IHC evaluation, only one cholangiocarcinoma had marked intracytoplasmic and membranous anti-CK7 immunolabeling (Fig.3F). No case of cholangiocarcinoma was positive in the IHC for anti-Hep Par-1.

\section{DISCUSSION}

The diagnosis of all PHN cases in this study was obtained through the association of the gross, histopathological, histochemical, and immunohistochemical findings. Liver neoplasms are considered uncommon when compared to other tumors of cattle (Lucena et al. 2011, Tessele \& Barros 2016, Reis et al. 2017). Usually, PHN in cattle are incidental findings of slaughterhouses (Tessele \& Barros 2016) or are diagnosed at the necropsy, wherein it may be related to the cause of death (Reis et al. 2017).

All cattle affected in this study were adults, aged three years or older, similar to that reported by other authors (Anderson \& Sandinson 1968, Wettimuny 1969, Braun et al. 2005, Jeong et al. 2005). Females were more affected than males, and, although few studies assessed a possible sex predilection for the development of liver tumors in cattle (Wettimuny 1969, Braun et al. 2005), in dogs and cats it is

Table 1. Histological features observed in $\mathbf{1 6}$ hepatocellular carcinomas

\begin{tabular}{lcccc}
\hline \multirow{2}{*}{ Feature } & \multicolumn{4}{c}{ Intensity } \\
\cline { 2 - 5 } & None & Mild & Moderate & Marked \\
\hline \multirow{2}{*}{ Pleomorphism } & - & - & $75 \%$ & $25 \%$ \\
& & $75 \%$ & $18.75 \%$ & $6.25 \%$ \\
Mitotic index & - & $(12 / 16)$ & $(3 / 16)$ & $(1 / 16)$ \\
& & $43.75 \%$ & $31.25 \%$ & - \\
Desmoplasia & $25 \%$ & $(7 / 16)$ & $(5 / 16)$ & \\
& $(4 / 16)$ & - & - & - \\
Mucin & $100 \%$ & & & - \\
\multirow{2}{*}{ Necrosis } & $(16 / 16)$ & & $31.25 \%$ & - \\
& $12.5 \%$ & $56.25 \%$ & $(5 / 16)$ &
\end{tabular}

known that there is no such predisposition (Patnaik et al. 1981, Trigo et al. 1982, Lawrence et al. 1994, Liptak et al. 2004, Flores et al. 2013, Van Sprundel et al. 2014). Probably females were overrepresented in this study since these are slaughtered later, and are thus, in the so-called "cancer age", as previously postulated (Reis et al. 2017).

In the present study, there was a predominance of hepatocellular carcinomas over cholangiocarcinomas. Most studies in cattle demonstrated similar ratios (Bastianello 1982, Bettini \& Marcato 1992, Lucena et al. 2011), with occasional exceptions (Anderson \& Sandinson 1968). PHN in this study had distinct gross morphological patterns. The vast majority of hepatocellular carcinomas were characterized by solitary masses or multifocal nodules, which are patterns commonly described in cattle (Anderson \& Sandinson 1968, Wettimuny 1969). Observation of this pattern can assist in a presumptive diagnosis at the gross examination. The diffuse pattern was an unusual presentation for hepatocellular carcinomas and observed in only two cases, which suggests a prolonged clinical evolution, which allowed an almost complete replacement of the healthy parenchyma.

The parenchyma of hepatocellular carcinomas may present a wide range of colors caused by hemorrhages, areas of necrosis, and cholestasis, including gray-white, red, brown, yellow, and dark-green (Wettimuny 1969, Bettini \& Marcato 1992). These variations occurred in the hepatocellular carcinomas of the current study. The green areas are a critical macroscopic characteristic and, combined with the pattern of distribution of the neoplasm, provide valuable clues for a gross presumptive diagnosis. Metastases from hepatocellular carcinomas are uncommon (Bettini \& Marcato 1992), but when they occur, the sites commonly affected include mediastinal lymph nodes, and lungs (Anderson \& Sandinson 1968). In our study, metastasis was observed by the meat inspector veterinarian in a single case involving the mediastinal lymph node.

In the cholangiocarcinomas of the current study, only the multinodular pattern was observed, similar to other cases with the same gross pattern in hepatocellular carcinomas (Ohfuji 2012, Azizi et al. 2016). In PHN, it is unclear whether multiple nodules arise from intrahepatic vascular metastases or multiple origins in different foci (Wettimuny 1969, Barros 2016). A distinctive feature that can help differentiate cholangiocarcinomas from other liver tumors is that they are frequently umbilicated. This presentation was present in one of the cases in this study and is generally attributed to intratumoral necrosis and subsequent retraction by fibrosis (Head et al. 2003, Cullen 2017). Although this does not represent a particular characteristic of cholangiocarcinomas, it is a helpful criteria for gross differentiation. Another feature of cholangiocarcinomas is desmoplasia, which gives these neoplasms a firm consistency (Cullen 2017), as observed in this study in which all three cases had this characteristic. Metastases are common in cholangiocarcinomas; the main secondary sites are the lungs, lymph nodes, and peritoneum (Anderson \& Sandinson 1968).

The cellular features of hepatocellular carcinomas and cholangiocarcinomas vary according to the degree of differentiation (Head et al. 2003, Cullen 2017). The pattern of cell growth in hepatocellular carcinoma includes trabecular, solid, pseudoglandular, or squamous (Cullen 2017). We detected two patterns: trabecular and solid. As previously 
stated, the trabecular pattern was the most common in cattle (Wettimuny 1969, Bundza et al. 1984, Bettini \& Marcato 1992). Necrotic foci and cavities filled with red blood cells are frequent (Wettimuny 1969, Schlageter et al. 2014) and were observed, respectively in $100 \%$ and $25 \%$ of the cases here reported. These histological characteristics, associated with the polygonal shape of the tumor cells, may help in the morphological diagnosis of these tumors. In one case, there

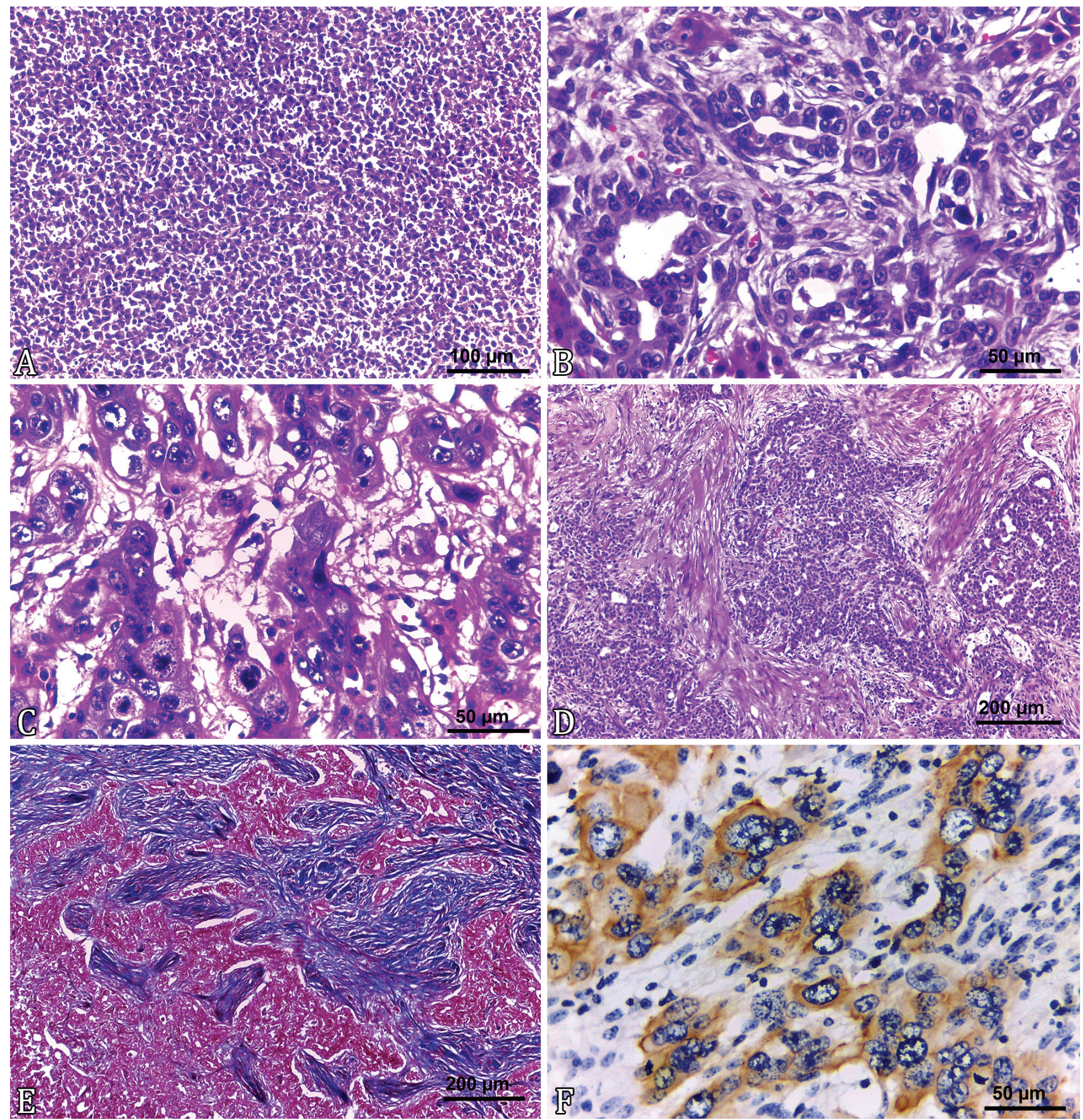

Fig.3. Histological and immunohistochemical aspects of cholangiocarcinomas in cattle. (A) Solid pattern. Neoplastic cells homogeneously replace the liver parenchyma. HE, bar $=100 \mu \mathrm{m}$. (B) Acinar pattern characterized by ductules immersed in an abundant fibrous stroma. The cells are cuboidal to rounded, with predominantly oval nuclei and one or more prominent nucleoli. HE, bar $=50 \mu \mathrm{m}$. (C) Cellular pleomorphism is characterized by marked anisocytosis, anisokaryosis, and occasional megalocytosis. Mitosis and occasional bi or multinucleated cells are evident. HE, bar $=50 \mu \mathrm{m}$. (D) A marked proliferation of fibrous connective tissue dissects and isolates groups of neoplastic cells. HE, bar $=200 \mu \mathrm{m}$. (E) Abundant fibrous connective tissue. MT, bar $=200 \mu \mathrm{m}$. (F) There is marked immunolabeling in the cytoplasm of neoplastic epithelial cells. Anti-CK-7 IHC, AEC chromogen, bar $=50 \mu \mathrm{m}$. 
was marked intracytoplasmic vacuolation; this is mentioned as a frequent finding in hepatocellular carcinomas and mainly related to glycogen or lipids accumulation within the cytoplasm of the neoplastic cells (Cullen 2017).

Cholangiocarcinomas may have acinar or tubular histological patterns, which, when well-differentiated, resemble the normal biliary epithelium (Barros 2016), while in undifferentiated tumors a solid pattern may predominate (Head et al. 2003, Cullen 2017). The solid pattern of cholangiocarcinoma was the most frequent in this study. Although the acinar patterns indicate fairly differentiation, in our study, this was not the case, as this pattern displayed marked cellular pleomorphism, high mitotic index, and vascular invasion. Fibrous connective tissue and mucin are classical histological findings of cholangiocarcinomas and valuable features for the recognition of this tumor (Head et al. 2003, Barros 2016, Cullen \& Stalker 2016, Cullen 2017). In the present cases, a pronounced desmoplasia was confirmed by MT technique, and a slight amount of mucin in the PAS staining was found in two of the cholangiocarcinoma cases.

Upon IHC technique, all hepatocellular carcinomas expressed Hep Par-1, while only one cholangiocarcinoma expressed CK7. The relative lack of immunolabeling in cholangiocarcinomas is probably due to the degree of differentiation. However, as there was also no labeling in the internal control (normal biliary epithelium), a prolonged fixation period in formaldehyde solution could be possible a factor involved. Previous studies have showed a decrease in the intensity of IHC-staining in some tissues after three days of exposure to formaldehyde and even an absence of immunostaining within seven days of fixation (Battifora \& Kopinski 1986, Leong \& Gilham 1989, Webster et al. 2009). However, a good sensitivity and specificity of Hep Par-1 was detected as a marker of normal and neoplastic hepatocytes in cattle, and the combined employment of anti-Hep Par-1 and anti-CK7 may contribute to improve the accuracy of PHN diagnosis in cattle.

Other neoplasms and tumor-like lesions should be considered as macroscopic differential diagnoses of PHN. Among neoplasms, metastatic carcinomas of different primary sources (squamous epithelium, pulmonary, and endometrial cells) and lymphoma should be included. Infectious or parasitic diseases such as degenerate hydatid cysts and tuberculosis (Cullen \& Stalker 2016, Kamelli et al. 2016, Brown et al. 2017, Faccin et al. 2018) may be considered as possible candidates for a gross dispute over a definitive diagnosis. In some cases, histological, histochemical, and immunohistochemical evaluation should be used for differentiation.

\section{CONCLUSIONS}

Hepatocellular carcinoma is the most common primary liver tumor in cattle. Adult cows, as they are allowed to reach the "cancer age", are more often affected than males.

Grossly, hepatocellular carcinomas were characterized by solitary masses or multifocal nodules, and their greenish color is an essential clue for tumor recognition.

Histologically, solid and trabecular patterns are the most common.

Cholangiocarcinomas appear macroscopically as multiple firm nodules, occasionally umbilicated, with a solid histologic arrangement.
Immunohistochemistry was an important tool to improve accuracy in the diagnosis of PHN. Hep Par-1 is a useful immunohistochemical marker for hepatocellular carcinomas.

Acknowledgments.- The authors thank the "Conselho Nacional de Desenvolvimento Científico e Tecnológico" (CNPq) and the "Coordenação de Aperfeiçoamento de Pessoal de Nível Superior" (CAPES) for supporting this study.

Statement of conflict of interest.- The authors declare no conflict of interest with respect to the publication of this paper.

\section{REFERENCES}

Anderson L.J. \& Sandinson A.T. 1968. Tumors of the liver in cattle, sheep and pigs. Cancer 21(2):289-301. <http://dx.doi.org/10.1002/10970142(196802)21:2<289::aid-cncr2820210219>3.0.co;2-c><PMid:4952507>

Azizi S., Kheirandiah R. \& Sami M. 2016. Slaughterhouse report of intrahepatic cholangiocarcinoma in a Holstein cow. Comp. Clin. Pathol. 25(6):1321-1324 <http://dx.doi.org/10.1007/s00580-016-2324-z>

Barros C.S.L. 2016. Fígado, vias biliares e pâncreas exócrino, p.224-228. In: Santos R.L. \& Alessi A.C. (Eds), Patologia Veterinária. $2^{a}$ ed. Roca, Rio de Janeiro.

Bastianello S.S. 1982. A survey on neoplasia in domestic species over a 40year period from 1935 to 1947 in the Republic of South Africa. I. Tumors occurring in cattle. Onderstepoort J.Vet Res. 49(4):195-204.<PMid:7185036>

Battifora H. \& Kopinski M. 1986. The influence of protease digestion and duration of fixation on the immunostaining of keratins. A comparison of formalin and ethanol fixation. J. Histochem. Cytochem. 34(8):1095-1100. <http://dx.doi.org/10.1177/34.8.2426335><PMid:2426335>

Bettini G. \& Marcato P.S. 1992. Primary hepatic tumours in cattle. A classification of 66 cases. J. Comp. Pathol. 107(1):19-34.<http://dx.doi.org/10.1016/00219975(92)90092-9><PMid:1331208>

Braun U., Nuss K., Soldati G. \& Essent P. 2005. Clinical and ultrasonographic findings in four cows with liver tumors. Vet. Rec. 157(16):482-484 <http://dx.doi.org/10.1136/vr.157.16.482> <PMid:16227385>

Brown D.L., Van Wettere A.J., Cullen J.M. 2017. Hepatobiliary system and exocrine pancreas, p.412-470. In: Zachary J.F. (Ed.), Pathologic Basis of Veterinary Disease. 6th ed. Elsevier, St Louis.

Bundza A., Greig A.S. \& Duke T.W. 1984. Primary hepatocellular tumors in animals killed at meat packing plants: report of 11 cases. Can. Vet. J. 25(2):82-85. <PMid:17422364>

Carvalho F.K.L., Dantas A.F.M., Riet-Correa F., Andrade R.L.F.S., Nóbrega Neto P.I., Miranda Neto E.G., Simões S.V.D. \& Azevedo S.S. 2014 Estudo retrospectivo das neoplasias em ruminantes e equídeos no semiárido do Nordeste Brasileiro. Pesq. Vet. Bras. 34(3):211-216. <http://dx.doi.org/10.1590/S0100-736X2014000300003>

Chan E.S. \& Yeh M.M. 2010. The use of immunohistochemistry in liver tumors. Clin. Liver Dis. 14(4):687-703. <http://dx.doi.org/10.1016/j. cld.2010.10.001><PMid:21055690>

Chu P., Ishizawa S., Wu E. \& Weiss L. 2002. Hepatocyte antigen as a marker of hepatocellular carcinoma: an immunohistochemical comparison to carcinoembryonic antigen, CD10, and alpha-fetoprotein. Am. J.Surg. Pathol. 26(8):978-88. <http://dx.doi.org/10.1097/00000478-200208000-00002> $<$ PMid:12170084>

Cullen J.M. \& Stalker M.J. 2016. Liver and biliary system, p.344-352. In: Maxie M.G. (Ed.), Jubb, Kennedy, and Palmer's Pathology of Domestic Animals. Vol.2. 6th ed. Elsevier, St Louis.

Cullen J.M. 2017. Tumors of the liver and gallbladder, p.602-631. In: Meuten D.J. (Ed.), Tumors in domestic animals. 5th ed. John Wiley and Sons Inc., Iowa. 
Faccin T.C., Cargnelutti J.F., Rodrigues F.S., Menezes F.R., Piazer J.V.M., Melo S.M.P., Lautert B.F., Flores E.F. \& Kommers G.D. 2018. Bovine upper alimentary squamous cell carcinoma associated with bracken fern poisoning: clinical-pathological aspects and etiopathogenesis of 100 cases. PLoS One 13(9):e0204656. <http://dx.doi.org/10.1371/journal.pone.0204656> $<$ PMid:30256853>

Flores M.M., Bianchi R.M., Kommers G.D., Irigoyen L.F., Barros C.S.L. \& Fighera R.A. 2013. Prevalência e achados epidemiológicos, anatomopatológicos e imuno-histoquímicos dos tumores hepáticos malignos primários de cães da Região Central do Rio Grande do Sul (1965-2012). Pesq. Vet. Bras. 33(4)497-511. <http://dx.doi.org/10.1590/S0100-736X2013000400014>

Food Safety Inspection Service 2013. Using dentition to age cattle. Food Safety Inspection Service, United States Department of Agriculture, Washington, D.C. Available at <http://www.fsis.usda.gov/ofo/tsc/bse_information.h> Accessed on Feb. 23, 2020.

Freitas M.R. 1999. Caracterização anatomopatológica de bursites cervicais de bovinos abatidos sob Inspeção Federal no Estado de Goiás. Master's Thesis in Animal Science, Escola de Veterinária, Universidade Federal de Goiás, Goiânia. 65p.

Head K.W., Cullen J.M., Dubielzig R.R., Else R.W., Misdorp W., Patnaik A.K., Tateyama S. \& Van der Gaag I. 2003. Histological classification of tumors of the alimentary system of domestic animals. Vol.5. 2nd series. Armed Forces Institute of Pathology, Washington, 257p.

Jeong W.I., Do S.H., Sohn M.H., Yun H.S., Kwon O.D., Kim T.H., Jeong D.H., Williams B.H. \& Jeong K.S. 2005. Hepatocellular carcinoma with metastasis to the spleen in a Holstein cow. Vet. Pathol. 42(2):230-232.<http://dx.doi.org/10.1354/ vp.42-2-230><PMid:15753480>

Kamelli M., Borji H. \& Naghibi A. 2016. Genetic identification of cattle hydatid cyst isolates from northeast and southwest of Iran. Ann. Parasitol. 62(4):301305. <http://dx.doi.org/10.17420/ap6204.65><PMid:28160770>

Lawrence H.J., Erb H.N. \& Harvey H.J. 1994. Nonlymphomatous hepatobiliary masses in cats: 41 cases (1972 to 1991). Vet. Surg. 23(5):365-368. <http://dx.doi.org/10.1111/j.1532-950x.1994.tb00496.x><PMid:7839594>

Leong A.S-Y. \& Gilham P.N. 1989. The effects of progressive formaldehyde fixation on the preservation of tissue antigens. Pathology 21(4):266-268. <http://dx.doi.org/10.3109/00313028909061071> <PMid:2483748>

Liptak J.M., Dernell W.S., Monnet E., Powers B.E., Bachand A.M., Kenney J.G. \& Withrow S.J. 2004. Massive hepatocellular carcinoma in dogs: 48 cases (1992-2002). J. Am. Vet. Med. Assoc. 225(8):1225-1230. <http://dx.doi.org/10.2460/javma.2004.225.1225> <PMid:15521445>

Lucena R.B., Rissi D.R., Kommers G.D., Pierezan F., Oliveira-Filho J.C., Macêdo J.T.S.A., Flores M.M. \& Barros C.S.L. 2011. A retrospective study of 586 tumours in Brazilian cattle. J. Comp. Path. 145(1):20-24. <http://dx.doi. org/10.1016/j.jcpa.2010.11.002> <PMid:21247583>

Mello L.S., Bianchi M.V., Bandinelli M.B., Sonne L., Driemeier D. \& Pavarini S.P. 2017. Causas de morte em vacas leiteiras no Rio Grande do Sul. Pesq. Vet. Bras. 37(9):916-920. <http://dx.doi.org/10.1590/s0100-736x2017000900003>
Ministério da Agricultura 2017. Regulamento da Inspeção Industrial e Sanitária de Produtos de Origem Animal (R.I.I.S.P.O.A). Aprovado pelo Decreto no. 9013/2017. Ministério da Agricultura, Brasília, DF. 66p.

Ohfuji S. 2012. Cholangiocarcinoma of possibly hepatic progenitor cell origin in a cow. Vet. Q. 32(3/4):183-186. <http://dx.doi.org/10.1080/016521 76.2012.749363>.

Patnaik A.K., Hurvitz A.I., Lieberman P.H. \& Johnson G.F. 1981. Canine bile duct carcinoma. Vet. Pathol. 18(4):439-444. <http://dx.doi. org/10.1177/030098588101800403><PMid:6266117>

Reis M. O., Slaviero M., Lorenzett M.P., Cruz R.A.S., Guimarães L.L.B., Pavarini S.P., Driemeier D. \& Sonne L. 2017. Neoplasmas bovinos diagnosticados no Setor de Patologia Veterinária da UFRGS, Porto Alegre (2005-2014). Pesq. Vet. Bras. 37(2):105-109. <http://dx.doi.org/10.1590/s0100736x2017000200002>

Rosa F.B., Kommers G.D., Lucena R.B., Galiza G.J.N., Tochetto C., Silva T.M. \& Silveira I.P. 2012. Aspectos epidemiológicos, clinicopatológicos e imunohistoquímicos de carcinomas de células escamosas vulvares em 33 vacas. Pesq. Vet. Bras. 32(11):1127-1132. <http://dx.doi.org/10.1590/S0100736X2012001100009>

Schlageter M., Terracciano L.M., Angelo S. \& Sorrentino P. 2014. Histopathology of hepatocellular carcinoma. World J. Gastoenterol. 20(43):15955-15964. <http://dx.doi.org/10.3748/wjg.v20.i43.15955><PMid:25473149>

Tessele B. \& Barros C.S.L. 2016. Tumores em bovinos encontrados em abatedouros frigoríficos. Pesq. Vet. Bras. 36(3):145-160. <http://dx.doi. org/10.1590/S0100-736X2016000300002>

Trigo F.J., Thompson H., Breeze R.G. \& Nash A.S. 1982. The pathology of liver tumours in the dog. J. Comp. Pathol. 92(1):21-39. <http://dx.doi. org/10.1016/0021-9975(82)90040-8> <PMid:6279705>

Van Sprundel R.G.H.M, Van den Ingh T.S.G.A.M., Guscetti F., Kershaw O., Van Wolferen M.E., Rothuizen J. \& Spee B. 2014. Classification of primary hepatic tumours in the cat. Vet. J. 202(2):255-266. <http://dx.doi.org/10.1016/j. tvjl.2014.07.002><PMid:25439443>

Webster J.D., Miller M.A., DuSold D. \& Ramos-Vara J. 2009. Effects of prolonged formalin fixation on diagnostic immunohistochemistry in domestic animals. J. Histochem. Cytochem. 57(8):753-761. <http://dx.doi.org/10.1369/ jhc.2009.953877><PMid:19398606>

Wettimuny S.G. 1969. Primary liver tumours of cattle in Ceylon. J. Comp. Pathol. 79(3):355-362. <http://dx.doi.org/10.1016/0021-9975(69)90050-4> $<$ PMid:4310553>

Yabushita K., Yamamoto K., Ibuki N., Okano N., Matsumura S., Okamoto R., Shimada N. \& Tsuji T. 2001. Aberrant expression of cytokeratin 7 as a histological marker of progression in primary biliary cirrhosis. Liver Int. 21(1):50-55. <http://dx.doi.org/10.1034/j.1600-0676.2001.210108.x> <PMid:11169073> 